\title{
Forest Biosecurity in Canada - An Integrated Multi-Agency Approach
}

\author{
Jeremy D. Allison ${ }^{1 *}$, Mireille Marcotte ${ }^{2}$, Meghan Noseworthy ${ }^{3}$ and Tod Ramsfield ${ }^{4}$ \\ ${ }^{1}$ Canadian Forest Service, Great Lakes Forestry Centre, Sault Ste. Marie, ON, Canada, ${ }^{2}$ Canadian Food Inspection Agency, \\ Ottawa, ON, Canada, ${ }^{3}$ Canadian Forest Service, Pacific Forestry Centre, Victoria, BC, Canada, ${ }^{4}$ Canadian Forest Service, \\ Northern Forestry Centre, Edmonton, AB, Canada
}

\section{OPEN ACCESS}

Edited by:

Angus J. Carnegie,

New South Wales Department

of Primary Industries, Australia

Reviewed by:

Simon Francis Shamoun,

Natural Resources Canada, Canada Johanna Witzell,

Swedish University of Agricultural

Sciences, Sweden

*Correspondence:

Jeremy D. Allison

jeremy.allison@canada.ca

Specialty section:

This article was submitted to

Pests, Pathogens and Invasions,

a section of the journal

Frontiers in Forests and Global

Change

Received: 26 April 2021

Accepted: 21 June 2021

Published: 14 July 2021

Citation:

Allison JD, Marcotte $M$

Noseworthy $M$ and Ramsfield T

(2021) Forest Biosecurity in Canada -

An Integrated Multi-Agency

Approach.

Front. For. Glob. Change 4:700825.

doi: 10.3389/ffgc.2021.700825
In Canada, forest biosecurity is primarily under federal jurisdiction as the federal government is the signatory to the International Plant Protection Convention and other international trade agreements. The Canadian Food Inspection Agency (CFIA), which is Canada's National Plant Protection Organization, has the mandate of analyzing risks, setting policy, and managing incursion responses related to forest biosecurity. Other federal government agencies play important roles; the Canada Border Services Agency (CBSA) enforces regulations at international ports of entry and the Canadian Forest Service of Natural Resources Canada conducts research and analysis in support of the development and implementation of phytosanitary regulations. The provinces and territories also manage invasive species through implementing regulations to prevent the spread of established forest pests. This paper outlines the regulatory framework for forest biosecurity within Canada, and provides case studies of species that have invaded Canadian forests or are anticipated to do so in the near future.

Keywords: invasive organisms, phytosanitary regulations, IPPC, incursion response, pest management

\section{INTRODUCTION TO CANADIAN FORESTS AND THEIR MANAGEMENT}

In Canada forests cover approximately 347 million hectares (90\% of which is publically owned), representing $40 \%$ of Canada's land cover, and comprising $9 \%$ of the world's forest area. The land mass of Canada ranges from $42^{\circ} \mathrm{N}$ to $83^{\circ} \mathrm{N}$ latitude and from $53^{\circ} \mathrm{W}$ to $141^{\circ} \mathrm{W}$ longitude, encompassing a wide variety of ecozones and forest regions (Figure 1). While the majority of Canada's forested land comprises naturally regenerated forest, $5 \%$ is planted forest (FAO, 2020). These forested lands are important to Canadians and the world for water regulation, carbon sequestration, habitat for biological diversity and the economy. Forest product trade contributed $\$ 23.7$ billion CAD to Canada's GDP in 2019 and provided jobs to over 204,000 people (Natural Resources Canada, 2020).

The term biosecurity has many definitions across jurisdictions; over the past 30 years, the concept has evolved with its application. Recently the Food and Agriculture Organization of the United Nations (FAO) reviewed biosecurity approaches and definitions across organizations and countries (Quinlan et al., 2016); however, a harmonized definition of the term has not been adopted into International Standards for Phytosanitary Measures (ISPM) 5, the Glossary of phytosanitary terms (IPPC Secretariat, 2021a). In the FAO Biosecurity Toolkit book, biosecurity is defined as "a strategic and integrated approach that encompasses the policy and regulatory frameworks 


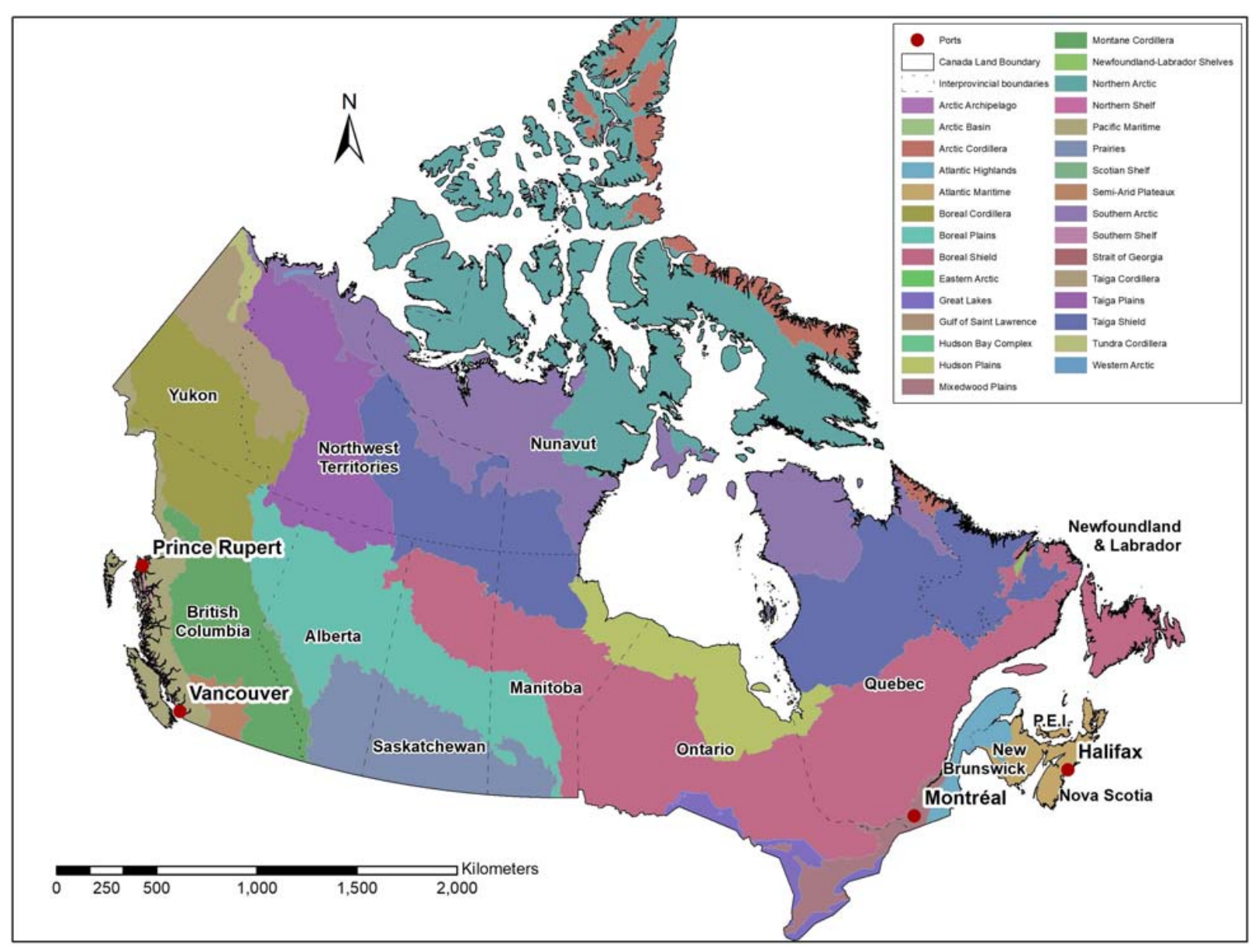

FIGURE 1 | Map of Canada, illustrating the different ecozones, provincial and territorial boundaries and the location of container ports. The CFIA is responsible for establishing import requirements for plants and plant products entering the country across international boundaries (solid line), based on pest risk assessments conducted by the CFIA and CFS. The CBSA is responsible for enforcement of those requirements at different critical entry points, such as the four main marine ports, airports and land border crossings. The CFIA enforces import requirements at other marine ports and at destination. Enforcement of interprovincial movement across provincial boundaries (dashed lines) is a shared responsibility between the CFIA (regulated pests) and provinces and territories (native pests).

(including instruments and activities) for analyzing and managing relevant risks to human, animal and plant life and health, and associated risks to the environment" (FAO, 2007).

Canada's forest biosecurity policy and regulatory frameworks are governed under a number of international agreements, and federal and provincial legislation. For example, the Invasive Alien Species Strategy for Canada was developed by the federal government in collaboration with provincial and territorial counterparts. This national biosecurity strategy identifies four priorities for protecting domesticated plants and animals and conserving native species: (i) prevention of new invasions; (ii) early detection of invaders if prevention fails; (iii) rapid response to new invaders; (iv) containment, eradication and control of established and spreading invaders (Government of Canada, 2004). Canada is obligated to conserve biodiversity under the Convention on Biological Diversity (Environment and Climate Change Canada, 2019). Through the Montreal Protocol, Canada is committed to sustainable forestry using sciencebased indicators and adhering to carbon emission mandates and agreements (Payne and Barnard, 2019). As a signatory to the International Plant Protection Convention (IPPC), Canada is committed to protect global plant resources through reducing the risk of spreading plant pests and promoting safe trade, following the guidance outlined in the ISPMs. At the federal level, Canada's Plant Protection Act and Regulations (S.C. 1990 , c. 22) aim to protect plant life and the agricultural and forestry sectors of the Canadian economy by preventing the import, export and spread of pests and by controlling or eradicating non-native quarantine pests in Canada. The CFIA is mandated to uphold the Plant Protection Act. Natural Resources Canada (NRCan) is mandated to ensure that Canada maintains market competitiveness and meets its global commitments to sustainably develop its natural resources, including forests under the Department of Natural Resources Act and Forestry Act through the Canadian Forest Service (CFS).

Canada is divided into ten provinces and three northern territories (Figure 1) that have jurisdiction over most of the country's forests and each of which individually develops and 
enforces laws, regulations and policies related to sustainable forest management that consider economic, social, and environmental values. For example, the province of Ontario has implemented the Ontario Invasive Species Strategic Plan, which includes the Ontario Invasive Species Act (Nienhuis and Wilson, 2018). Protection and management of Canada's forests is a shared responsibility that requires collaboration among federal, provincial, territorial, municipal and indigenous governments and other stakeholders including the forest industry and nongovernment agencies. While this review acknowledges that provincial, territorial, municipal and indigenous governments and non-government organizations play an important role in forest biosecurity in Canada, it emphasizes a federal perspective.

Together, the CFS, CFIA, provincial and territorial governments, as well as municipal and indigenous governments, work to manage, and protect Canada's forests with responsibilities at different levels. The federal government is responsible for international safe trade of forest products and federal lands and parks, the provincial and territorial governments are responsible for the management of forest pests, promoting forest health while managing sustainable harvest volumes and governing agreements with forest harvesting companies including mandating requirements for regeneration of harvested areas by harvesting companies (Canadian Council of Forest Ministers, 2021). Municipal governments have a role in managing invasive species in urban environments, which is key to preventing the establishment of invasive forest pests in natural areas adjacent to cities (Figure 2).

Foreign market access for Canadian forest products is dependant on demonstrating low pest risk associated with forest product exports. The CFIA, CFS, and provincial and territorial governments work together to support market access through sound scientific analyses and implementation of risk mitigation measures for forest products. Within Natural Resources Canada, the CFS conducts research, in collaboration with researchers in the provinces and academia on a case-by-case basis, to support sustainable forest management including pest risk management to mitigate introduction pathways for non-native pests. Efforts to mitigate the risk of exporting pests to Canadian trade partners are often specific to trade relationships and pathways and fall outside the focus of this review.

Given the breadth and diversity as well as the ecological and economic importance of Canada's forests, management of forest biosecurity is constantly evolving and improving. Historical and recent examples of the impacts of non-native pest introductions and approaches to addressing incursions and introductions, illustrate both the challenges and successes of past, current and potential future collaborations between different jurisdictions.

\section{EFFECTS OF INVASIONS ON FOREST ECOSYSTEMS}

Invasions have complex ecological and economic impacts. Successful invasion by an exotic pest requires that it arrive, become established and then spread (Brockerhoff and Liebhold, 2017). Many species are introduced outside their native range but few become established and later result in negative ecological and economic consequences. For example, while Haack (2006) reported 8,341 interceptions from seven families of Coleoptera from 1985 to 2000 at US ports of entry, Aukema et al. (2010) estimated that in US forests 2.5 new non-native insect herbivores establish annually. The majority of non-native species have no known ecological impacts, this, at least in part, is likely due to an incomplete understanding of complex phenomena as well as delayed effects (Crooks, 2005; Aikio et al., 2010; Aukema et al., 2010; Yelenik and D'Antonio, 2013).

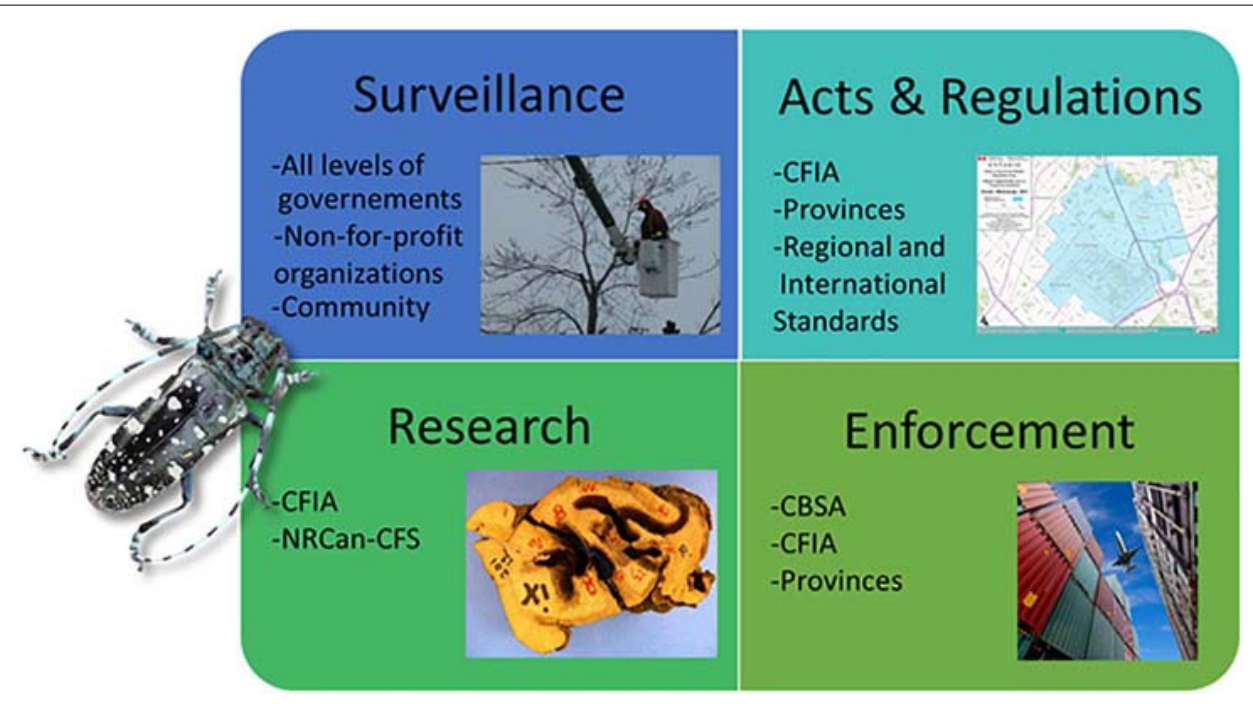

FIGURE 2 | Multi-agency integrated approach to forest biosecurity as illustrated by the Asian longhorned beetle, Anoplophora glabripennis responses in Toronto, Canada. Photos: Asian longhorned beetle, Mike Bohne USDA-FS FHP; the Surveillance, Acts \& Regulations, and Enforcement images come from the CFIA and the Research image from the laboratory of Jean Turgeon CFS. 
Although disturbances (e.g., fire, insect outbreaks, disease) are inherent to normal forest dynamics, the direct and indirect effects of invasive species can alter forest ecology and the ability of forest ecosystems to provide services (Stadler et al., 2005; Boyd et al., 2013). Among the most apparent ecological impacts in forest ecosystems are those associated with pests (both insects and pathogens) that damage or kill trees. These pests change the nature of competitive interactions to favor non-host species, which can result in changes to tree species composition and altered successional patterns. For example, the emerald ash borer, Agrilus planipennis Fairmaire (Coleoptera: Buprestidae) has killed millions of ash trees in North America and functionally removed this common tree from areas near the epicenter of the invasion (Klooster et al., 2013; Herms and McCullough, 2014). Similarly, Dutch elm disease, caused by the pathogens Ophiostoma ulmi (Buisman) Nannfeldt and Ophiostoma novoulmi Brazier, has caused extensive mortality of American elm (Ulmus americana Linnaeus) across eastern Canada (Hubbes, 1999) and the provinces have invoked regulations to prevent the spread of the disease (e.g., Manitoba, 1998; Saskatchewan, 2005; CFIA, 2010; Alberta, 2021).

In addition to mortality and reduced growth, non-native species have numerous indirect effects on North American forests. For example, emerald ash borer-induced ash mortality results in cascading direct and indirect effects that include altered forest food webs (particularly for native species that exploit ash trees), microenvironments, nutrient cycles, successional trajectories, understory plant communities including facilitation of invasive plants, and increased coarse woody debris (Herms and McCullough, 2014). Invasive defoliators can alter the degree of light penetration, transpiration rates, carbon sequestration and storage, water dynamics, drainage and storage, and nitrogen and carbon flows (Stadler et al., 2005; Lovett et al., 2006; Kenis et al., 2009; Boyd et al., 2013). In some cases these impacts are transient but in other cases they appear to be permanent. In addition to the individual effects, it has been suggested that invasive species can "collectively" impact ecosystems and act as "mega-disturbances" (Millar and Stephenson, 2015).

The success of the arrival of an invasive species can be further complicated by interactions between non-native species and other species in the invaded range. For example, facilitation occurs when one species improves the success of another species by providing limiting resources, reducing competition or predation, or forms a mutualism with another species (Lucero et al., 2019). In Canada, one significant example of facilitation is the invasion and spread of Dutch elm disease (first caused by the pathogen Ophiostoma ulmi followed by Ophiostoma novo-ulmi), which requires a vector. Invasion by the European smaller elm bark beetle, Scolytus multistriatus (Marsham) has facilitated invasion by the causative agent of Dutch elm disease (Webber, 2000).

Accurate and complete estimates of the costs associated with invasive species are difficult to produce and consequently, few exist. Most estimates of the costs associated with invasive species are restricted to traditional market impacts and management costs. For example, Pedlar et al. (2020a) estimate the potential replacement and removal costs of Asian longhorned,
Anoplophora glabripennis (Motschulsky) beetle-killed street trees in eastern Canada between $\$ 8.6$ and 12.2 billion CAD, timber losses as $\$ 431$ million CAD annually and edible maple products as $\$ 358$ million CAD annually. Although it is clear that the economic costs associated with the disruption of ecosystem services (e.g., reduced regulating and cultural services) can exceed the costs of losses to traditional markets (Holmes et al., 2009; Rosenberger et al., 2012; Kenis et al., 2017b), ecosystem impacts are difficult to monetize (Boyd et al., 2013). Generating these estimates is complicated by the population dynamics of the invading species. Often there is a time lag between arrival and establishment and the realization of impacts. This can be a function of the population dynamics of the non-native species and/or a failure to recognize and document impacts in real time. For example, emerald ash borer impacts were not reported until at least 10 years after its establishment in North America (Siegert et al., 2014). Conversely, some invasive species experience rapid and dramatic increases in population density and then collapse for a multitude of reasons (Simberloff and Gibbons, 2004).

\section{DRIVERS OF INVASIONS}

Several interacting features of invasive species, the pathways by which they travel, and the habitats they invade appear to determine invasion success. Drivers of invasions in forest ecosystems are incompletely understood. It is clear that some traits predispose species to success in some or all phases of the invasion process. For example, insects have diverse reproductive traits including parthenogenesis, sex determination mechanisms, reproductive parasites, and mating strategies, each of which can affect invasion success (Queffelec et al., 2020). Pathways that facilitate invasion are also clearly important, although it can be difficult to determine the relative effects of species traits and pathways. For example, Hemiptera are well represented among invasive taxa. Many of these invasive species reproduce asexually and as a group Hemiptera are over-represented in invasion pathways (Liebhold et al., 2012, 2016). As a result, the relative contribution of reproductive traits and propagule pressure to the invasion success of the Hemiptera is unknown.

Propagule pressure clearly influences invasion success (Lockwood et al., 2005). In general, evidence suggests for both intentional (Hopper and Roush, 1993) and accidental (Brockerhoff et al., 2014) introductions, species released or arriving in higher numbers are more likely to establish. Variation in the spatial and temporal patterns of establishment rates of non-native species likely reflect variation in propagule pressure (Aukema et al., 2010; Liebhold et al., 2013). Propagule pressure is a function of both pathway volume (i.e., the amount and frequency of trade) and population levels in the point of origin. For example, Lymantria dispar asiatica Vnukovskij (Lepidoptera: Erebidae) have been observed to arrive outside their range during periods of outbreak in native populations (Gray, 2010). The elevated risk associated with outbreak populations is recognized in recommendations for certifying marine vessels moving commodities from regulated countries to countries in North America during the high-risk period (female flight), 
from infested areas (NAPPO, 2017, 2021). Regarding pathway volume, changing patterns of trade should be reflected in the arrival and establishment of non-native species. Historically, western Europe was the dominant trading partner for Canada and the United States, but recently trade with northeast Asia has increased significantly. Liebhold et al. (2017a) demonstrated that this shifting pattern of trade from Europe to Asia is reflected in the changes in the assemblage of species of bark and ambrosia beetles that have invaded the US as trade patterns have changed.

Invasion by insect herbivores and pathogens are also likely influenced by the availability of their host. In terms of host availability, as plant diversity increases, so too could the likelihood of establishment. In part, it is for this reason that urban areas, which have highly diverse tree species compositions, are targeted by the CFIA for surveillance for invasive pests. However, it has been suggested that at the spatial scale of forest ecosystems, as tree diversity increases, the density of natural enemies also increases while the density of individual hosts decreases. As a result the probability of establishment of invasive herbivores may be reduced (Jactel et al., 2006; Rigot et al., 2014).

\section{PLANT BIOSECURITY SYSTEMS IN CANADA: THEORY}

As most non-native species in forest ecosystems have been introduced accidentally, invasive species management programs in Canada focus on prevention. Prevention efforts in Canada emphasize pathways and commodities with historically high propagule pressure. One important pathway for invasive forest pests, particularly bark and woodboring insects, has been dunnage and wood packaging material (Haack, 2006; Brockerhoff et al., 2006; Liebhold et al., 2012). For example, it is thought that both the Asian longhorned beetle and emerald ash borer invaded North America through this pathway. In an attempt to manage this pathway, the International Plant Protection Convention requires phytosanitary treatment of wood packaging material moving in international trade (ISPM-15) (Haack et al., 2014; Leung et al., 2014). Another high-risk pathway is imported live plants and in recognition of this many governments (including Canada) regulate this pathway (Kiritani and Yamamura, 2003; Liebhold et al., 2012; MacLeod et al., 2010; IPPC Secretariat, 2021a).

Our knowledge of the pathways involved in the invasion of forest ecosystems in Canada is primarily based on border interception records, risk assessments for pests and pathways, surveillance programs, and participation in international research networks (e.g., the International Forest Quarantine Research Group). Although these are valuable sources of information, they have limited predictive power. For example, although the bark beetle Ips typographus L. has been intercepted hundreds of times by North American authorities (Haack, 2001) it has never established in North America. While policies developed for prevention have reduced propagule pressure, it is not possible to completely close all pathways and as a result, invasions continue to occur. Further, although these policies result in reductions in propagule pressure, concomitant increases in trade volume offset these reductions and may lead to increased propagule pressure (Liebhold et al., 2017a).

Two mechanisms that likely contribute to the success of many invasions of forest ecosystems are enemy release and lack of host resistance (Liebhold et al., 2017b). Understanding which mechanism(s) contribute to the success of an invasive species has important management consequences. Classical biological control has clear potential as a management option when enemy release is involved. The enemy release hypothesis is predicated on the theory that populations in the invaded range are less constrained by natural enemies than populations in the native range (Colautti et al., 2004). For example, the winter moth, Operophtera brumata L., caused extensive defoliation of hardwood trees in Nova Scotia until two biological control agents from the native range were released in the invaded range (Embree, 1965). Tree breeding for the development of resistance is the dominant management strategy when naïve hosts are involved. Both biological control and tree breeding are considered when the pest has become established and eradication is no longer possible (i.e., the emerald ash borer). The lack of resistance appears to be most common among species that have a close association with their host, like tree pathogens and bark and woodboring insects (Villari et al., 2016). For example, the emerald ash borer has caused significant damage to naïve ash trees in North America (Herms and McCullough, 2014). The objective of classical biological control is often the establishment of lower equilibrium population densities of the invasive species, while the breeding and careful planting of resistant trees attempts to restore forest ecosystems (Muzika, 2017).

\section{PLANT BIOSECURITY SYSTEMS IN CANADA: PRACTICE}

Plant biosecurity systems in Canada, much like in the rest of the world, include measures and regulations implemented preborder, at the border, and post-border. By far the most cost effective pest management strategy is prevention. Mitigating risks at origin or pre-border (i.e., off-shore mitigation) is arguably the most effective preventative plant biosecurity option. Canada's National Plant Protection Organization, the CFIA aims to do this by establishing national import requirements for plants and plant products based on risks associated with the commodities, their intended use and their origin. For example, a phytosanitary certificate, issued by the National Plant Protection Organization may be required. The certificate attests that the commodities are free from specific pests or provides details of the approved phytosanitary treatment applied prior to entry as a means to eliminate pests of concern. When a new invasive pest emerges, import pathways are reviewed to ensure that the potential new risks are adequately mitigated with the import requirements in place or to decide if changes are warranted. Import requirements are often established for specific commodities but they can also be designed for an entire pathway, such as requirements for wood packaging materials, where wood packaging materials moving in international trade must be heat treated or fumigated in accordance with ISPM 15 (IPPC Secretariat, 2019a). 
At the border, the CBSA inspects goods as they enter Canada at ports, land border crossings and airports. Given the increasing volume of goods crossing the Canadian border annually, not all of these goods can be inspected to determine compliance with phytosanitary regulations. Using commercial information provided to the CBSA, risk assessments are performed to target goods in advance of their arrival in Canada. Plants and plant products identified as a potential threat to Canada are referred for examination upon their arrival at a port of entry (CBSA, 2016). Work done by the CFIA at the border complements that of the CBSA. For example, to determine compliance of wood packaging material, the CBSA focuses its efforts on inspecting and enforcing compliance at the four main Canadian commercial marine ports of entry (Halifax, Montreal, Vancouver, and Prince Rupert) (Figure 1), while the CFIA enforces compliance at the other marine ports (CBSA, 2014). Additionally, the CFIA conducts land-border inspections in partnership with the CBSA at selected strategic land-border crossings (referred to as "border blitzes") in order to verify compliance of imported products (CFIA, 2020a).

Post-border inspection at destination is another biosecurity approach and phytosanitary measure used to reduce risks of pest introduction. In this context, the terms biosecurity approach and phytosanitary measure mean "any legislation, regulation or official procedure having the purpose to prevent the introduction and/or spread of quarantine pests, or to limit the economic impact of regulated non-quarantine pests" (IPPC Secretariat, 2021a). Commodities such as plants for planting, which are plants intended to remain planted, to be planted or replanted (IPPC Secretariat, 2020), may be subject to inspection and audit sampling on arrival in Canada to verify compliance with CFIA requirements. Shipments selected for inspection may not be opened or moved into the production area until they have been released by a CFIA inspector (CFIA, 2015a).

Although these pre-border, border and post-border efforts undoubtedly reduce the entry of plant pests into Canada, some incursions and introductions do occur. Therefore, surveys and controls are implemented to detect and subsequently control and/or eradicate quarantine pests. Annual pest surveys are conducted across the country by the CFIA and numerous other organizations, such as the CFS, Environment and Climate Change Canada, Parks Canada, provinces, territories and municipalities, as well as non-profit organizations and community scientists. Surveillance programs target pest species that are known to be invasive. The identification of pest species of concern through risk analysis can be challenging as many invasive species behave differently in the invaded range compared to the native range (e.g., Liu et al., 2020). This is one reason why scientists and regulators meet regularly in international forums such as the Plant Health Quadrilateral Working Group and the USDA interagency research forum on invasive species.

Pest surveys support Canada's plant biosecurity in a number of ways. Detection surveys are conducted to detect populations of pests newly introduced in the country or out of known range within the country. Some surveys are designed to target specific pests, such as Lymantria dispar, for which surveillance is conducted nationally to monitor dispersal of the European strain and identify potential incursions of the Asian strain. Other surveys are designed to monitor for a wider variety of forest pests. One of these is the CFIA's Invasive Alien Species Forest Trapping survey. This survey is deployed annually in Canada and is not designed to sample for specific pests, rather to sample the community present (e.g., woodborers) to look for non-native species (CFIA, 2020b). This general survey relies mostly on combinations of host volatiles and generic pheromone blends on a rotating basis; research conducted by the CFS has been instrumental in the development and refinement of the Invasive Alien Species protocol over time (e.g., Flaherty et al., 2019; Li et al., 2017; Rassati et al., 2019).

When a potential pest is detected by members of the public in Canada, there is an obligation to report it to the CFIA (Government of Canada, 1990). A specimen will then be analyzed by one of the CFIA plant health laboratories for official identification. Actions taken related to the detection will depend on whether the specimen has been intercepted on an imported commodity or in the environment. In both cases, if the risk associated with the pest is unknown, a pest categorization, and if needed, a pest risk assessment, will be conducted, and as per ISPM 11 (IPPC Secretariat, 2019b). In that case, the CFIA will involve subject matter experts as required, such as researchers from the CFS, academia and foreign governments, to gather the information needed to perform the risk assessment. Most pest risk assessments are developed by the CFIA-Plant Health Risk Assessment unit but some have been jointly authored with CFS experts (e.g., Phytophthora ramorum Werres, de Cock and Man in 't Veld).

For pests intercepted on imported commodities, surveillance activities in the area surrounding the detection site will be carried out to ensure that no individuals have escaped and established in the environment. If no additional individuals are found, subsequent measures will likely not be implemented. However, if the pest is found in the environment, a delimitation survey will also be executed to characterize the infestation and determine the extent of the pest distribution. Canada is obligated to report the detection to its trading partners (IPPC Secretariat, 2017). Canadian partners (e.g., federal, provincial and municipal governments, and trading partners) and stakeholders (e.g., indigenous peoples, industry associations, non-profit organizations, and general public) will also be informed. The pest risk assessment can also identify some knowledge gaps (e.g., in terms of pest biology, economic and environmental risks, and mitigation options). Those gaps are identified by the CFIA as research needs that are shared within the organization as well as with researchers in other organizations (e.g., federal labs, and academia).

The information gathered from the pest risk assessment and the delimitation survey will allow the CFIA to determine if the pest meets the definition of a quarantine pest (also referred to as a regulated pest); "a pest of potential economic importance to the area endangered thereby and not yet present there, or present but not widely distributed and being officially controlled" (IPPC Secretariat, 2021a). If the spread is limited, eradication may be attempted. Although some successful eradications have been achieved (e.g., Anoplophora glabripennis, Asian longhorned beetle and some local populations of Lymantria dispar in Western 
Canada), eradication is much more likely if populations are detected early in the invasion process. Unfortunately, some species are difficult to detect at low densities and eradication is normally not feasible (Brockerhoff et al., 2010; Liebhold et al., 2016). When detection occurs after populations reach high levels and eradication is not deemed feasible or when the costs related to eradication outweigh the benefits, the CFIA determines if regulatory actions are the best approach to prevent and/or slowthe-spread (Sharov et al., 2002) of the pest to other areas of Canada. In some instances movement restrictions of host and potentially infested material have had very little impact on the spread of invasive pests. However, to attempt to limit the economic and environmental impacts of the pest, as well as to maintain market access for wood products originating in different areas of Canada, regulations and a slow-the-spread approach may be warranted.

If a slow-the-spread approach is adopted, surveillance must continue to determine if the pest has spread beyond its known distribution. High risk sites and suitable habitats are targeted and protocols are reviewed annually to optimize sensitivity of surveillance tactics. A collaborative approach, utilizing the skill sets of partner agencies, is often the best way to manage forest pest incursions and to limit the impact of the newly introduced pest. For example, there are provincial regulations related to the intraprovincial transport of elm material for Dutch elm disease (Ophiostoma ulmi and Ophiostoma novoulmi) (Manitoba, 1998; Saskatchewan, 2005; CFIA, 2010; Alberta, 2021). Dutch elm disease is also listed in Schedule II of the Plant Protection Regulations (Plant Protection Act), which lists organisms for which movement in Canada is restricted (Government of Canada, 1990). Therefore, the CFIA enforces interprovincial movement restrictions and import requirements to prevent the introduction and spread of this pest in noninfested areas of Canada (CFIA, 2010). A similar approach was in place for balsam wooly adelgid (BWA, Adelges piceae Ratz.) in British Columbia (BC), where the province was managing intra- and inter-provincial movement restrictions to protect the interior of BC while the CFIA was prohibiting the import of Abies material from infested areas of the United States (Zilahi-Balogh et al., 2017). Federal and provincial regulations related to BWA were repealed in 2019 given that the pest had reached the interior of BC (CFIA, 2019; Province of British Columbia, 2020).

When an established pest is detected, multi-partnered collaborative task forces are put in place for a rapid and efficient response. These task forces mainly include participants from federal, provincial and municipal governments but can also include experts from academia and foreign governments. For example, an integrated collaborative approach was used for the management of the Asian longhorned beetle infestations detected in the Toronto area in 2003 and in 2013. In both cases eradication was the management approach that was implemented (see section Case Study "Asian Longhorned Beetle"). Another example of highly functional multi-agency collaboration is the eradication program in place for Japanese beetle, Popillia japonica Newman, in Vancouver, BC. This program has been in place since 2017 and involves the CFIA, the province of BC, the city of Vancouver and non-profit organizations. In these collaborative management approaches, the CFIA focuses its efforts on surveillance, the establishment and enforcement of regulated areas and on communications and public awareness, while partners develop and implement treatments, and contribute to communication and enforcement efforts (CFIA, 2020c).

Communications related to pest finds are also critical components of forest biosecurity in Canada. Partners, stakeholders and the public can play a crucial role in the detection and delimitation of a pest, as well as in the promotion of compliance with regulatory actions that are in place. For example, it is well known that the movement of firewood can be an important mechanism for forest pest dispersal (Gagné et al., 2017; Morrison et al., 2017; Haack et al., 2010). Paid social media campaigns targeting people interested in outdoor activities, such as camping, are used by the CFIA and its partners to educate community members of the risks associated with moving firewood and to encourage buying and burning firewood locally. Similarly, social media messaging related to pests of concern, encouraging community scientists to report sightings of pests via online applications, distribution of outreach products at public events (such as fridge magnets, bag clips, temporary tattoos and pest cards) and training sessions for stakeholders are all used to raise awareness about plant pests, promote early detection and slow the spread. National and provincial invasive species councils and plant protection advisory councils also play an important role in sharing information among agencies and informing the public about pests present in the country as well as potential threats. In 2018, the Canadian Plant Health Council was created to facilitate collaboration between plant health partners including, Canadian governments, industry and academia, and promote implementation of the Plant and Animal Health Strategy for Canada (Government of Canada, 2017).

Validation of reported detections is required as false positives are frequent but an educated and vigilant population is invaluable for the early detection of pests. In Canada, reports from the public often lead to important detections. For example, the two established populations of Asian longhorned beetle in Ontario were detected by community members. The first provincial records of emerald ash borer in Manitoba, Quebec, New Brunswick and Nova Scotia were also reported by community members. Similarly, the recent detection of the first record of the elm zigzag sawfly, Aproceros leucopoda Takeuchi, in North America was reported by a community member in the province of Quebec.

Forest pest infestations are dynamic and it is essential that regulatory approaches are reviewed periodically, and adjusted as appropriate, in order to ensure that risk-mitigation and resource usage are effective and appropriate. Cost-benefit analyses are increasingly being used to assess needs for regulatory revisions, at both the provincial (Sun et al., 2019) and national (Bogdanski et al., 2018; Hope et al., 2020) levels. For example, as a result of regulatory reviews, the regulated areas for the emerald ash borer and the brown spruce longhorn beetle, Tetropium fuscum (Fabricius), were expanded in 2014 and 2015, respectively, to reduce regulatory burden, increase awareness of the regulated areas, and maximize compliance with movement restrictions (CFIA, 2014, 2015b). Similarly, as established invasive species 
reach the limits of their potential distribution in the invaded range and the costs of regulations in place are no longer warranted, deregulation is considered [e.g., Pine shoot beetle, Tomicus piniperda (L.) (CFIA, 2020d)].

\section{CASE STUDIES}

\section{White Pine Blister Rust}

Unfortunately, the introduction and establishment of Cronartium ribicola J.C. Fisch. over 100 years ago has caused substantial damage to Canadian forests. The pathogen causes white pine blister rust, a serious disease of 5-needle pines and is hypothesized to be native to Asia (Hunt, 2009). It is believed that the pathogen was introduced into eastern North America through the importation into the United States of infected white pine seedlings from Germany, France, and Holland in the early 1900s (Geils et al., 2010). Introduction of the pathogen into western North America also likely occurred via importation of infected plant material, although Hunt (2009) has suggested that the history of introduction is likely more complex than a single introduction of 1000 eastern white pine seedlings imported from France into Vancouver in 1910 as stated by Mielke (1943). In Canada, the pathogen has caused extensive damage to commercial western white pine (Pinus monticola Dougl. Ex. D. Don) and eastern white pine (P. strobus L.), and has also contributed to the decline of whitebark pine ( $P$. albicaulis Engelm.) (Figure 3) and limber pine ( $P$. flexilis James) in the Rocky Mountains. The severity of the pathogen, the potential for widespread damage to Canada's 5-needle pines, and the necessity of management activities, were raised in the early 1900's by Gussow (1916). He warned of the consequences of the presence of the pathogen in Canada and recognized the importance of pathway management and delimiting surveys. Although the importation of 5-needle pines into Canada was banned (Gussow, 1916), the pathogen has become widespread and activities have shifted from eradication to management.

There have been multiple consequences associated with the establishment of white pine blister rust in Canada. The volume of eastern and western white pine on the landscape has declined due the combined effects of mortality from disease as well as foresters shifting to alternative species to avoid future losses to the pathogen (Hunt, 2009; Ostry et al., 2010). As a result of white pine blister rust, mortality of both whitebark pine (Shepherd et al., 2018) and limber pine (Smith et al., 2013) has been observed, and both species have been assigned the status of "Endangered" by the Committee on the Status of Endangered Wildlife in Canada (COSEWIC, 2010, 2014). Whitebark pine is listed on Schedule 1 of the federal Species at Risk Act (SARA, 2021a) while limber pine is currently under consideration for addition to the list (SARA, 2021b). Breeding for resistance to C. ribicola has been identified as important for the long term survival of these pines and research to identify resistant stock and develop breeding programs has been extensive within the United States and Canada (King et al., 2010). Clearly the introduction of this pathogen has had extensive impacts, both economically and on ecosystem services, that provide ample justification for current regulations and activities that have been implemented to prevent the establishment of exotic pests.

\section{Asian Longhorned Beetle}

The following case study is an example of a multi-partnered coordinated approach in which different organizations from multiple levels of government worked together (Figure 2). The end result was the successful eradication of the Asian longhorned beetle, a pest of high concern in Canada. An established population of Asian longhorned beetle was detected by a member of the public for the first time in Toronto, Canada in September 2003. The specimen was submitted to the CFIA entomology lab for identification. A pest risk assessment had already been done for that species and thus response actions were able to be implemented rapidly. As a number of populations of Asian longhorned beetle have been successfully eradicated around the world (e.g., EPPO, 2013; Trotter et al., 2019) and the negative impact of this pest on the Canadian economy would be significant (Anonymous, 2008), it was clear to the CFIA that eradication should be attempted to protect Canada's plant resources and maintain pest-free status (IPPC Secretariat, 2021b) which is important for trade.

A delimitation survey was conducted shortly after the official identification to delimit the core infestation and any satellite populations. Surveys were delivered by the CFIA with the collaboration of the Ontario Ministry of Natural Resources, NRCan-CFS, the Cities of Toronto and Vaughan, York Region, and Toronto and Region Conservation Authority. The USDA was also involved in discussions to share information about their experience managing the Asian longhorned beetle. The delimitation survey results led to the establishment of a $152 \mathrm{~km}^{2}$ regulated area in Toronto/Vaughan to prevent the movement of potentially infested material out of that area. Furthermore, a total of 15,000 trees were removed between November 2003 and April 2004. Trees removed included infested trees, trees suspected to be infested and all trees from high risk genera within $400 \mathrm{~m}$ of infested trees. The CFS chaired a science sub-committee, comprised of representatives from various organizations, responsible for providing scientific advice to the CFIA on surveillance protocols and management options. A number of partners and stakeholders were engaged to develop a collaborative management plan (CFIA, 2007).

A total of 28,700 trees were removed between November 2003 and March 2013 from the regulated area. After 5 consecutive years of negative surveys, the Asian longhorned beetle was declared eradicated. Unfortunately, 4 months later, a community member in Mississauga, Ontario reported a specimen of the Asian longhorned beetle, $2 \mathrm{~km}$ away from the boundary of the first regulated area. A $47 \mathrm{~km}^{2}$ regulated area was quickly established and the CFIA worked once again with partners and stakeholders. That population was determined to be an undetected satellite of the first infestation (Turgeon et al., 2015). A total of 7,800 trees were removed and eradication was declared in June 2020.

A number of key factors have been identified as critical for the two successful eradications of the Asian longhorned beetle in Canada. One of them is surveillance, conducted as per IPPC 

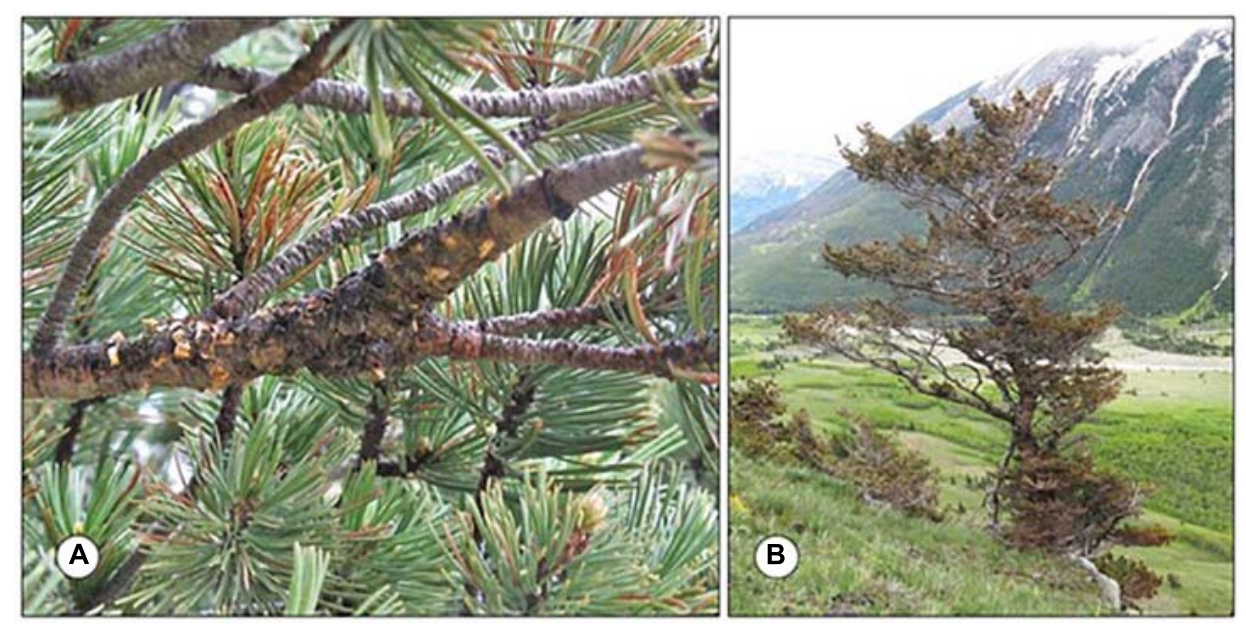

FIGURE 3 | Whitebark pine (Pinus albicaulis) infected by Cronartium ribicola in southern Alberta. (A) Infected branch with ruptured aecia from which aeciospores have been released. (B) Solitary whitebark pine infected by C. ribicola. Photos, Tod Ramsfield.

guidelines (e.g., ISPM 6 and 8), to detect and delimit pest infestations, as well as guidance from ISPM 9 for eradication programs (IPPC Secretariat, 2016, 2019c, 2021b). Another key factor for success was the CFIA's reliance on science for evidencebased decision-making. NRCan-CFS chaired a science committee which provided a number of critical recommendations based on science to the CFIA such as a robust host list, the development of a grid-based surveillance approach, guidance on which host genera to include in tree removal and distance from infested trees to consider for tree removal, and wood chip size to mitigate risks related to disposal of trees. Early engagement of partners and proactive communication to increase public awareness and reporting were also critical to these successes.

\section{Oak Wilt}

A tree disease of concern to Canada is oak wilt, caused by the pathogen Bretziella fagacearum (Bretz) Z.W. de Beer, Marinc., T.A. Duong, and M.J. Wingf (formerly Ceratocystis fagacearum) (De Beer et al., 2017). The pathogen was first recorded in the United States in the early 1940s and its range has slowly expanded such that it is now present in the states that border the province of Ontario (Juzwik et al., 2011). Although the pathogen has not been recorded in Canada (CFIA, 2019a,b; Nienhuis and Wilson, 2018), climatic suitability modeling suggests that climate would not be limiting and that serious economic consequences could occur if the pathogen became established here (Pedlar et al., 2020b).

Long distance spread of the pathogen occurs due to the close association with sap beetles (Coleoptera: Nitidulidae) that carry the pathogen to fresh wounds on damaged oaks, leading to infection of the tree. Growth of the pathogen within the vascular system, and the response of the host to infection, cause a disruption in sap flow and symptomatic wilting of foliage. Once the tree is colonized, it is possible for the pathogen to spread to adjacent trees through root grafts, leading to the development of a disease center. One characteristic of the disease process is the formation of pressure pads formed by fungal mycelium at the cambium. These pressure pads lead to cracks in the bark and the volatile compounds released by the mycelium are attractive to the insect vectors. Susceptibility to the disease varies between hosts; oaks in the red oak group succumb to the disease much more readily than oaks in the white oak group (Juzwik and Appel, 2016).

In response to the close proximity of the disease to the Canadian border and the potential threat posed by the disease to oaks in Canada, the CFIA led the development of an oak wilt response framework to guide an incursion response should that be required (CFIA, 2019a). The framework was developed collaboratively by the Oak Wilt Technical Advisory Committee, which included representatives from federal, provincial and municipal governments as well as representatives from New York and Michigan. The framework is a foundational document that clearly outlines the biology of the pathogen and its vectors, regulations that are in place to prevent introduction, and an incursion response plan. Keys to regulation include the fact that oak wilt is regulated under the federal Plant Protection Act, various CFIA directives related to imports, and enforcement tools that can be used in the event of a violation of the act. The response framework outlines the necessary steps to prevent establishment of the pathogen in Canada. Steps include a communication strategy, detection and monitoring, and necessary management activities to eradicate the pathogen if it is discovered in Canada. An important part of the response framework has been the identification of research needs and subsequent funding of research to address specific aspects of the pathosystem to provide knowledge and tools to prevent the establishment of the pathogen in Canada.

Oak wilt has caused serious damage to oak populations in the United States. It has slowly spread through states in the northeast and is also present in Texas (Juzwik et al., 2011) and it threatens oaks in Canada due to its proximity to the Canadian border. Through activities led by the CFIA, Canada has taken action to prevent the establishment of the pathogen and has 
developed incursion response plans to facilitate a rapid response in the event that the pathogen is discovered in Canada, thus increasing the probability of successful eradication. Through awareness campaigns such as pest fact sheets [e.g., CFIA (2019b); the Invasive Species Centre (2018)], Canadian citizens have also been provided with information on oak wilt disease, further protecting oaks in Canada.

\section{CONCLUSION/SUMMARY}

The Canadian approach to forest biosecurity emphasizes prevention with strategies and policies enacted pre-border, at the border, and post-border. These strategies and policies are developed by the CFIA in consultation with stakeholders (federal, provincial, territorial, municipal, indigenous, and industry), guided by standards for phytosanitary measures and informed by research, in particular by the Canadian Forest Service. The close relationship that exists between the CFIA and CFS on forest biosecurity is quite unusual in the world. Additionally, their ongoing international collaborations with researchers across the world through groups like the International Forest Quarantine Research Group and their involvement in expert panels with the North American Plant Protection Organization and the International Plant Protection Convention, allow both the CFS and CFIA to access cutting edge biosecurity research to the advantage of Canadian biosecurity. The Canada Border Services Agency plays an important role in enforcing regulations enacted by the CFIA. If an incursion response is required, the CFIA, provinces and municipalities would all be involved. Opportunities for improvement of forest biosecurity in Canada are being developed and include increased inter-agency integration of information generated by pre-border, at the border and post-border biosecurity actions with research activities and policy development. Pre-border information sharing with trading

\section{REFERENCES}

Aikio, S., Duncan, R. P., and Hulme, P. E. (2010). Lag-phases in alien plant invasions: separating the facts from the artefacts. Oikos 119, 370-378. doi: 10.1111/j.1600-0706.2009.17963.x

Alberta (2021). Dutch Elm Disease Prevention / Control Measures. Responsibilities and Authority Under the APA. Government of Alberta. Available online at: https://open.alberta.ca/publications/dutch-elm-diseaseprevention-control-measures-responsibilities-authority-apa (accessed April 21, 2021).

Anonymous (2008). Benefit-Cost Analysis of the CFIA Management Program for Brown Spruce Longhorn Beetle, Asian Long-horned Beetle and Emerald Ash Borer. Halifax: Gardner Pinfold Consulting Economists Ltd, 85.

Aukema, J. E., McCullough, D. G., Von Holle, B., Liebhold, A. M., Britton, K., and Frankel, S. J. (2010). Historical accumulation of non-indigenous forest pests in the continental US. Bioscience. 60, 886-897. doi: 10.1525/bio.2010.60.11.5

Bogdanski, B. E. C., Corbett, L., Dyk, A., and Grypma, D. (2018). Pine Shoot Beetle, Tomicus Piniperda (Linnaeus): Analysis of Regulatory Options for Canada. Canadian Forest Service Pacific Forestry Centre Information report BC-X-443. Victoria, British Columbia: The Pacific Forestry Centre, Natural Resources Canada.

Boyd, I. L., Freer-Smith, P. H., Gilligan, C. A., and Godfray, H. C. J. (2013). The consequence of tree pests and diseases for ecosystem services. Science 342:1235773. doi: $10.1126 /$ science. 1235773 partners on pest outbreaks, and sentinel planting networks, for example, can improve prevention strategies. Combining risk-based sampling and targeting inspection programs and interception data collection and analysis at the border can improve inspection effectiveness and help streamline and reduce inspection pressure. Post-border opportunities include several new and emerging technologies (e.g., data collection, integration and sharing through smart technologies (Naidoo et al., 2019); technological advances allowing for in-field chemical analyses and optimization of surveillance programs [e.g., Pawson et al., 2020)] that allow the development of much more precise biosurveillance and management tools more rapidly than has been possible to date (see Slippers et al., 2020 for a discussion of the potential of precision pest management in forestry). Building a sound scientific understanding of pest biology, epidemiology and trade economics is essential in the development of effective forest biosecurity policy. Combining science-based policies with strategic and efficient border security and collaborations among government and non-government stakeholders are keys to successful forest biosecurity.

\section{AUTHOR CONTRIBUTIONS}

JA took lead on synthesizing sections and the editorial process. All authors contributed to the writing of the manuscript and contributed equally to the development of the ideas in this manuscript.

\section{ACKNOWLEDGMENTS}

We are grateful to Jean-Luc St. Germain and Gwylim Blackburn for helpful reviews of the manuscript and Roger Brett for developing the map in Figure 1.

Brockerhoff, E. G., Bain, J., Kimberley, M., and Knížek, M. (2006). Interception frequency of exotic bark and ambrosia beetles (Coleoptera: Scolytinae) and relationship with establishment in New Zealand and worldwide. Can. J. For Res. 36, 289-298. doi: 10.1139/x05-250

Brockerhoff, E. G., Kimberley, M., Liebhold, A. M., Haack, R. A., and Cavey, J. F. (2014). Predicting how altering propagule pressure changes establishment rates of biological invaders across species pools. Ecology 95, 594-601. doi: 10.1890/ 13-0465.1

Brockerhoff, E. G., and Liebhold, A. M. (2017). Ecology of forest insect invasions. Biol. Invasions. 19, 3141-3159. doi: 10.1007/s10530-017-1514-1

Brockerhoff, E. G., Liebhold, A. M., Richardson, B., and Suckling, D. M. (2010). Eradication of invasive forest insects: concepts, methods, costs and benefits. N.Z. J. For Sci. 40, S117-S135.

Canadian Council of Forest Ministers. (2021). Sustainable forest management policies in Canada. Available online at: https://www.sfmcanada.org/en/ publications (accessed February 1, 2021). ** web

CBSA (2014). Wood Packaging Material Import Requirements. Available online at: https://www.cbsa-asfc.gc.ca/security-securite/wp-meb-eng.html (accessed November 27, 2020).

CBSA (2016). Evaluation of the Canada Border Services Agency Targeting Program. Available online at: https://www.cbsa-asfc.gc.ca/agency-agence/ reports-rapports/ae-ve/2016/tp-pc-eng.html (accessed November 27, 2020).

CFIA. (2007). Toronto-Vaughan Eradication Plan for the Asian Long-horned Beetle, Anoplophora Glabripennis (Motchulsky). 17. **Copmp. 
CFIA (2010). D-97:07:Phytosanitary Requirements for the Importation From the United States and Domestic Movement of Elm Material (Ulmus spp. and Zelkova spp.) to Prevent the Introduction and Spread of Dutch Elm Disease Ophiostoma ulmi (Buisman) Nannf. and Ophiostoma Novo-ulmi (Brasier) Within Canada. Available online at: https://www.inspection.gc.ca/plant-health/plant-pests-invasive-species/ directives/forest-products/d-97-07/eng/1323853706282/1323853796330 (accessed November 27, 2020).

CFIA (2014). RMD-13-01: Regulated Areas for Emerald ash Borer (EAB) (Agrilus Planipennis Fairmaire). Available online at: https://www.inspection.gc.ca/ plant-health/plant-pests-invasive-species/directives/pest-risk-management/ emerald-ash-borer/eng/1368741925939/1368741926892 (accessed November 27, 2020).

CFIA (2015a). D-08-04: Plant Protection Import Requirements for Plants and Plant Parts for Planting. Available online at: https://www.inspection.gc.ca/ plant-health/plant-pests-invasive-species/directives/horticulture/d-08-04/ eng/1323752901318/1378910413423 (accessed November 27, 2020).

CFIA (2015b). Notice to Industry - Transitioning to a Province-Wide Regulated Area for BSLB. Available online at: https://www.inspection.gc.ca/planthealth/plant-pests-invasive-species/insects/brown-spruce-longhorn-beetle/ notice-to-industry-2015-05-01/eng/1430483429514/1430483689473 (accessed November 29, 2020)

CFIA (2019). RMD-19-03: Pest Risk Management Document for the Deregulation of Adelges Piceae (Ratzeburg) (Balsam Woolly Adelgid) in British Columbia. 10. ${ }^{* *}$ Copl.

CFIA (2019a). Oak Wilt Response Framework for Canada. Available online at: https://www.inspection.gc.ca/plant-health/plant-pests-invasive-species/plantdiseases/oak-wilt/response-framework/eng/1563898431188/1563898479048 (accessed March 9, 2021).

CFIA (2019b). Bretziella Fagacearum (Previously Known as Ceratocystis Fagacearum (Oak Wilt)) - Fact Sheet. Available online at: https: //www.inspection.gc.ca/plant-health/plant-pests-invasive-species/plantdiseases/oak-wilt/fact-sheet/eng/1325629194844/1325632464641 (accessed March 9, 2021).

CFIA (2020a). Food Shipments Refused Entry Into Canada. Available online at: $\quad$ https://www.inspection.gc.ca/about-cfia/transparency/regulatorytransparency-and-openness/compliance-and-enforcement/refused-entry/ eng/1324305448701/1324305531127 (accessed November 27, 2020).

CFIA (2020b). Invasive Alien Species Forest Trapping Survey Protocol. Ottawa, ON: Canadian Food Inspection Agency, 20.

CFIA (2020c). A Coordinated Response to Eradicate Japanese Beetle in Vancouver. Available online at: https://www.inspection.gc.ca/plant-health/plant-pestsinvasive-species/insects/japanese-beetle/jb-vancouver/eng/1525800137593/ 1525800137983 (accessed November 27, 2020).

CFIA (2020d). Pine Shoot Beetle - Tomicus Piniperda L. Available online at: https:/www.inspection.gc.ca/plant-health/plant-pests-invasive-species/ insects/pine-shoot-beetle/eng/1328217170980/1328217251199_ (accessed November 29, 2020)

Colautti, R. I., Ricciardi, A., Grigorovich, I. A., and MacIsaac, H. J. (2004). Is invasion success explained by the enemy release hypothesis? Ecol. Lett. 7, 721-733. doi: 10.1111/j.1461-0248.2004.00616.x

COSEWIC (2010). COSEWIC Assessment and Status Report on the Whitebark Pine Pinus albicaulis in Canada. Committee on the Status of Endangered Wildlife in Canada. Ottawa: COSEWIC, 44.

COSEWIC (2014). COSEWIC Assessment and Status Report on the Limber Pine Pinus Flexilis in Canada. Committee on the Status of Endangered Wildlife in Canada. Ottawa: COSEWIC, 49.

Crooks, J. A. (2005). Lag times and exotic species: the ecology and management of biological invasions in slow-motion. Ecoscience 12, 316-329. doi: 10.2980/ i1 195-6860-12-3-316.1

De Beer, Z. W., Marincowitz, S., Duong, T. A., and Wingfield, M. J. (2017) Bretziella, a new genus to accommodate the oak wilt fungus, Ceratocystis fagacearum (Microascales, Ascomycota). MycoKeys 27, 1-19. doi: 10.3987/ mycokeys.27.20657

Embree, D. G. (1965). The population dynamics of the winter moth in Nova Scotia, 1954-1962. Mem. Entomol. Soc. Can. 97, 5-57. doi: 10.4039/entm9746fv

Environment and Climate Change Canada (2019). Summary of Canada's 6th National Report to the Convention on Biological Diversity. Gatineau, QC: Government of Canada.
EPPO (2013). Anoplophora glabripennis: Procedures for official control. EPPO Bull. 43, 510-517. doi: 10.1111/epp.12064

FAO (2007). FAO Biosecurity Toolkit: Food and Agriculture Organization of the United Nations. Biosecurity Priority Area for Interdisciplinary Action. Rome, Italy: Food \& Agriculture Org, 128.

FAO (2020). Global Forest Resources Assessment 2020 Report Canada. Rome: FAO. Flaherty, L., Gutowski, J. M. G., Hughes, C., Mayo, P., Mokrzycki, T., Pohl, G., et al. (2019). Pheromone-enhanced lure blends and multiple trap heights improve detection of bark and wood-boring beetles potentially moved in solid wood packaging. J. Pest. Sci. 92, 309-325. doi: 10.1007/s10340-018-1 019-4

Gagné, J., Al Zayat, M., and Nisbet, J. (2017). Firewood Pathway Analysis for Canada. Invasive Species Centre. 44. Available online at: https://www.ccfm.org/ english/coreproducts-forestpests.asp (accessed November 27, 2020).

Geils, B. W., Hummer, K. E., and Hunt, R. S. (2010). White pines, Ribes, and blister rust: a review and synthesis. For. Path. 40, 147-185. doi: 10.1111/j.1439-0329. 2010.00654.x

Government of Canada (1990). Plant Protection Act (SC 1990, c 22.). Available online at: https://laws-lois.justice.gc.ca/eng/acts/P-14.8/ (accessed November 27, 2020).

Government of Canada (2004). The Canadian Invasive Species Strategy. 44. Available online at: http://publications.gc.ca/collections/collection_2014/ec/ CW66-394-2004-eng.pdf (accessed April 6, 2021).

Government of Canada (2017). Plant and Animal Health Strategy for Canada. Available online at: https://inspection.canada.ca/about-cfia/transparency/ consultations-and-engagement/partnerships-pahs/draft-for-consultationpurposes/eng/1490390513931/1490390586446?chap $=0$ (accessed on April 6, 2021).

Gray, D. R. (2010). Hitchhikers on trade routes: a phenology model estimates the probabilities of gypsy moth introduction and establishment. Ecol. Appl. 20, 2300-2309. doi: 10.1890/09-1540.1

Gussow, H. T. (1916). Canada's white pine possessions threatened with extermination - an authoritative discussion of white pine blister rust. Bull. Can. For. Assoc. 28:7. doi: 10.1080/07060660609507362

Haack, R. A. (2001). Intercepted scolytidae (Coleoptera) at U.S. ports of entry: 1985-2000. Int. Pest Manag. Rev. 6, 253-282. doi: 10.1023/A:10257152 00538

Haack, R. A. (2006). Exotic bark- and wood-boring Coleoptera in the United States: recent establishments and interceptions. Can. J. For. Res. 36, 269-288. doi: $10.1139 / \mathrm{x} 05-249$

Haack, R. A., Britton, K. O., Brockerhoff, E. G., Cavey, J. F., Garrett, L. J., Kimberley, M., et al. (2014). Effectiveness of the international phytosanitary standard ISPM No. 15 on reducing wood borer infestation rates in wood packaging material entering the United States. PLoS ONE 9:e96611. doi: 10.1371/journal.pone. 0096611

Haack, R. A., Petrice, T. R., and Wiedenhoeft, A. C. (2010). Incidence of barkand wood-boring insects in firewood: a survey at Michigan's mackinac bridge. J. Econ. Entomol. 103, 1682-1692. doi: 10.1603/EC10041

Herms, D. A., and McCullough, D. G. (2014). Emerald ash borer invasion of North America: history, biology, ecology, impacts, and management. Annu. Rev. Entomol. 59, 13-30. doi: 10.1146/annurev-ento-011613-162051

Holmes, T. P., Aukema, J. E., VonHolle, B., Liebhold, A., and Sills, E. (2009). Economic impacts of invasive species in forests past, present, and future. The year in ecology and conservation biology. Ann. N. Y. Acad. Sci. 1162, 18-38. doi: 10.1111/j.1749-6632.2009.04446.x

Hope, E., Sun, L., McKenney, D., Bogdanski, B. E. C., Pedlar, J., Macaulay, L., et al. (2020). Emerald Ash Borer, Agrilus planipennis: An Economic Analysis of Regulations in Canada. Edmonton: Natural Resources Canada, Canadian Forest Service, 28.

Hopper, K. R., and Roush, R. T. (1993). Mate finding, dispersal, number released, and the success of biological control introductions. Ecol. Entomol. 18, 321-331. doi: 10.1111/j.1365-2311.1993.tb01108.x

Hubbes, M. (1999). The American elm and Dutch elm disease. For. Chron. 75, 265-273. doi: $10.5558 / \mathrm{tfc} 75265-2$

Hunt, R. S. (2009). History of western white pine and blister rust in British Columbia. For. Chron. 85, 516-520. doi: 10.5558/tfc85516-4

Invasive Species Centre (2018). Oak Wilt an Invasive Pathogen on Canada's Doorstep. Available online at: https://invasivespeciescentre.ca/wp-content/ uploads/2020/03/oak_wilt_factsheet_2018.pdf (accessed March 9, 2021). 
IPPC Secretariat (2016). ISPM 9: Guidelines for Pest Eradication Programmes. Rome: FAO on behalf of the Secretariat of the International Plant Protection Convention.

IPPC Secretariat (2017). ). ISPM 17: Pest Reporting. Rome: FAO on behalf of the Secretariat of the International Plant Protection Convention.

IPPC Secretariat (2019a). ISPM 15: Regulation of Wood Packaging Material in International Trade. Rome: FAO on behalf of the Secretariat of the International Plant Protection Convention.

IPPC Secretariat (2019b). ISPM 11: Pest Risk Analysis for Quarantine Pests. Rome: FAO on behalf of the Secretariat of the International Plant Protection Convention.

IPPC Secretariat (2019c). ISPM 6: Surveillance. Rome: FAO on behalf of the Secretariat of the International Plant Protection Convention.

IPPC Secretariat (2021a). ISPM 5: Glossary of Phytosanitary Terms [as Adopted by $C P M-14]$. Rome: FAO on behalf of the Secretariat of the International Plant Protection Convention.

IPPC Secretariat (2020). ISPM 36. Integrated Measures for Plants for Planting. Rome: FAO on behalf of the Secretariat of the International Plant Protection Convention.

IPPC Secretariat (2021b). ISPM 8. Determination of Pest Status in Area. Rome: FAO on behalf of the Secretariat of the International Plant Protection Convention.

Jactel, H., Menassieu, P., Vetillard, F., Gaulier, A., Samalens, J. C., and Brockerhoff, E. G. (2006). Tree species diversity reduces the invasibility of maritime pine stands by the bast scale, Matsucoccus feytaudi (Homoptera: Margarodidae). Can. J. For Res. 36, 314-323. doi: 10.1139/x05-251

Juzwik, J., and Appel, D. N. (2016). "Oak Wilt: Diseases of Trees in the Great Plains," in Gen. Tech. Rep. RMRS-GTR-335, eds A. D. Bergdahl and A. Hill (Fort Collins, CO: U.S. Department of Agriculture, Forest Service \& Rocky Mountain Research Station), 229

Juzwik, J., Appel, D. N., MacDonald, W. L., and Burks, S. (2011). Challenges and successes in managing oak wilt in the United States. Plant Dis. 95, 888-900. doi: 10.1094/PDIS-12-10-0944

Kenis, M., Auger-Rozenberg, M.-A., Roques, A., Timms, L., Péré, C., Cock, M. J. W., et al. (2009). Ecological effects of invasive alien insects. Biol. Invasions. 11, 21-45. doi: 10.1007/s10530-008-9318-y

Kenis, M., Roques, A., Santini, A., and Liebhold, A. (2017b). "Impact of nonnative invertebrates and pathogens on market forest tree resources," in Impact of biological invasions on ecosystem services, eds M. Vilà and P. E. Hulme (Cham: Springer), 103-117. doi: 10.1007/978-3-319-45121-3_7

King, J. N., David, A., Noshad, D., and Smith, J. (2010). A review of genetic approaches to the management of blister rust in white pines. For. Path. 40, 292-313. doi: 10.1111/j.1439-0329.2010.00659.x

Kiritani, K., and Yamamura, K. (2003). "Exotic insects and their pathways for invasion," in Invasive species: vectors and management strategies, ed. J. Carlton (Washington: Island Press), 44-67.

Klooster, W. S., Herms, D. A., Knight, K. S., Herms, C. P., McCullough, D. G., Smith, A., et al. (2013). Ash (Fraxinus spp.) mortality, regeneration, and seed bank dynamics in mixed hardwood forests following invasion by emerald ash borer (Agrilus planipennis). Biol. Invasions 16, 859-873. doi: 10.1007/s10530013-0543-7

Leung, B., Springborn, M. R., Turner, J. A., and Brockerhoff, E. G. (2014). Pathwaylevel risk analysis: the net present value of an invasive species policy in the US Front. Ecol. Environ. 12:273. doi: 10.1890/130311

Li, Y., Meng, Q., Silk, P. J., Gao, W., Mayo, P., and Sweeney, J. D. (2017). Effect of semiochemicals and trap height on catch of Neocerambyx raddei in Jilin province, China. Entomol. Exp. Appl. 164, 94-101. doi: 10.1111/eea. 12600

Liebhold, A. M., Brockerhoff, E. G., Garrett, L. J., Parke, J. L., and Britton, K. O. (2012). Live plant imports: the major pathway for forest insect and pathogen invasions of the US. Front. Ecol. Environ. 10:135. doi: 10.1890/110198

Liebhold, A. M., Brockerhoff, E. G., and Kimberley, M. (2017a). Depletion of heterogeneous source species pools predicts future invasion rates. J. Appl. Ecol. 54, 1968-1977. doi: 10.1111/1365-2664.12895

Liebhold, A. M., Brockerhoff, E. G., Kalisz, S., Nuñez, M. A., Wardle, D. A., and Wingfield, M. J. (2017b). Biological invasions in forest ecosystems. Biol. Invasions 19, 3437-3458. doi: 10.1007/s10530-017-1458-5

Liebhold, A. M., McCullough, D. G., Blackburn, L. M., Frankel, S. J., Von Holle, B., and Aukema, J. E. (2013). A highly aggregated geographical distribution of forest pest invasions in the USA. Divers. Distrib. 19, 1208-1216. doi: 10.1111/ ddi.12112

Liebhold, A. M., Yamanaka, T., Roques, A., Augustin, S., Chown, S. L., Brockerhoff, E. G., et al. (2016). Global compositional variation among native and non-native regional insect assemblages emphasizes the importance of pathways. Biol. Invasions 18, 893-905. doi: 10.1007/s10530-016-1079-4

Liu, C., Wolter, C., Xian, W., and Jeschke, J. M. (2020). Species distribution models have limited transferability for invasive species. Ecol. Lett. 23, 1682-1692. doi: 10.1111/ele.13577

Lockwood, J. L., Cassey, P., and Blackburn, T. (2005). The role of propagule pressure in explaining species invasions. Trends Ecol. Evol. 20, 223-228. doi: 10.1016/j.tree.2005.02.004

Lovett, G. M., Canham, C. D., Arthur, M. A., Weathers, K. C., and Fitzhugh, R. D. (2006). Forest ecosystem responses to exotic pests and pathogens in eastern North America. Bioscience 56, 395-405.

Lucero, J. E., Noble, T., Haas, S., Westphal, M., Butterfield, H. S., and Lortie, C. J. (2019). The dark side of facilitation: native shrubs facilitate exotic annuals more strongly than native annuals. NeoBiota 44, 75-93.

MacLeod, A., Pautasso, M., Jeger, M. J., and Haines-Young, R. (2010). Evolution of the international regulation of plant pests and challenges for future plant health. J. Food Secur. 2, 49-70. doi: 10.1007/s12571-010-0054-7

Manitoba (1998). Dutch Elm Disease Regulations. Man Reg 213/98. Available online at: https:/www.canlii.org/en/mb/laws/regu/man-reg-213-98/66199/man-reg213-98.html (accessed on November 27, 2020).

Mielke, J. L. (1943). White Pine Blister Rust in Western North America. Available online at: https://elischolar.library.yale.edu/yale_fes_bulletin/56.

Millar, C. I., and Stephenson, N. L. (2015). Temperate forest health in an era of emerging megadisturbance. Science 349, 823-826. doi: 10.1126/science.aaa9933

Morrison, A., Sweeney, J., Hughes, C., and Johns, R. (2017). Hitching a ride: Firewood as a potential pathway for range expansion of an exotic beech leafmining weevil, Orchestes fagi (Coleoptera: Curculionidae). Can. Entomol. 149, 129-137. doi: 10.4039/tce.2016.42

Muzika, R. M. (2017). Opportunities for silviculture in management and restoration of forests affected by invasive species. Biol. Invasions 19, 3419-3435. doi: 10.1007/s10530-017-1549-3

Naidoo, S., Slippers, B., Plett, J. M., Coles, D., and Oates, C. N. (2019). The road to resistance in forest trees. Front. Plant Sci. 10:273. doi: 10.3389/fpls.2019.00273

NAPPO (2017). RSPM 33: Guidelines for Regulating the Movement of Vessels from Areas Infested with Asian Gypsy Moth. Available online at: https://www.nappo. org/english/products/regional-standards-phytosanitary-measures-rspm (accessed March 20, 2021).

NAPPO (2021). Risks Associated with the Introduction of Exotic Tussock Moth Species (Lepidoptera: Erebidae: Lymantriinae) of Potential Concern to the NAPPO Region. NAPPO Science and Technology Document ST 07. North Carolina, USA: NAPPO, 31.

Natural Resources Canada (2020). The State of Canada's Forests: Annual Report 2020. Ottawa, ON: Natural Resources Canada, 96.

Nienhuis, S., and Wilson, R. (2018). Invasive species in Ontario: The thread, the strategy, and the law. For. Chron. 94, 97-102. doi: 10.5558/tfc2018-015

Ostry, M. E., Laflamme, G., and Katovich, S. A. (2010). Silvicultural approaches for the management of eastern white pine to minimize impacts of damaging agents. For. Path. 40, 332-346. doi: 10.1111/j.1439-0329.2010.00661.x

Pawson, S. M., Kerr, J. L., O’Connor, B., Lucas, P., Martinez, D., Allison, J. D., et al. (2020). Light-weight portable electroantennography device as a future field-based tool for applied chemical ecology. J. Chem. Ecol. 46, 557-566. doi: 10.1007/s10886-020-01190-6

Payne, T. W., and Barnard, T. D. (2019). Progress Towards the Conservation and Sustainable Management of Temperate and Boreal Forests: Overview and Country Highlights from the Montréal Process. Rotorua, NZ: Scione Research Publication, 41.

Pedlar, J. H., McKenney, D. W., Yemshanov, D., and Hope, E. S. (2020a). Potential economic impacts of Asian longhorned beetle (Coleoptera: Cerambycidae) in Eastern Canada. J. Econ. Entomol. 113, 839-850.

Pedlar, J. H., McKenney, D. W., Hope, E., Reed, S., and Sweeney, J. (2020b). Assessing the climatic suitability and potential economic impacts of oak wilt in Canada. Sci. Rep. 10:19391. doi: 10.1038/s41598-020-75549-w

Province of British Columbia. (2020). Balsam Woolly adelgid. Available online at: https://www2.gov.bc.ca/gov/content/industry/agriculture-seafood/ 
animals-and-crops/plant-health/insects-and-plant-diseases/nursery-andornamentals/balsam-woolly-adelgid (accessed November 27, 2020).

Queffelec, J., Allison, J. D., Greeff, J. M., and Slippers, B. (2020). Influence of reproductive biology on establishment capacity in introduced Hymenoptera species. Biol. Invasions 23, 387-406. doi: 10.1007/s10530-020-02 375-6

Quinlan, M. M., Alden, J., Habbel, F., and Murphy, R. (2016). The Biosecurity Approach: A Review and Evaluation of its Application by FAO, Internationally and in Various Countries. Rome: FAO, 87.

Rassati, D., Marini, L., Marchioro, M., Rapuzzi, P., Magnani, G., Poloni, R., et al. (2019). Developing trapping protocols for wood-boring beetles associated with broadleaf trees. J. Pest. Sci. 92, 267-279. doi: 10.1007/s10340018-0984-y

Rigot, T., van Halder, I., and Jactel, H. (2014). Landscape diversity slows the spread of an invasive forest pest species. Ecography 37, 648-658. doi: 10.1111/j.16000587.2013.00447.x

Rosenberger, R. S., Bell, L. A., Champ, P. A., and Smith, E. L. (2012). Nonmarket Economic Values of Forest Insect Pests: An Updated Literature Review. General Technical Report RMRS-GTR-275WWW. Albany, California: USDA Forest Service.

SARA (2021a). Whitebark Pine. Available online at: https://wildlife-species.canada. $\mathrm{ca} /$ species-risk-registry/species/speciesDetails_e.cfm?sid=1086 (accessed February 26, 2021).

SARA (2021b). Limber pine. Available online at: https://species-registry.canada.ca/ index-en.html\#/species/1275-933 (accessed February 26, 2021).

Saskatchewan (2005). The Dutch Elm Disease Regulations. Chapter F19.1 Reg 5 (effective February 3, 2005) as Amended by Saskatchewan Regulations 106/2017. The Forest Resources Management Act. Government of Saskatchewan. 17. Available online at: https://publications.saskatchewan. ca/api/v1/products/9601/formats/14558/download (accessed November 27, 2020).

Sharov, A. A., Leonard, D., Liebhold, A. M., Roberts, E. A., and Dickerson, W. (2002). "Slow the spread" A national program to contain the gypsy moth. J. Forestry 100, 30-35.

Shepherd, B., Jones, B., Sissons, R., Cochrane, J., Park, J., Smith, C. M., et al. (2018). Ten years of monitoring illustrates a cascade of effects of white pine blister rust and focuses whitebark pine restoration in the Canadian rocky and Columbia Mountains. Forests 9:138. doi: 10.3390/f9030138

Siegert, N. W., McCullough, D. G., Liebhold, A. M., and Telewski, F. W. (2014). Dendrochronological reconstruction of the epicentre and early spread of emerald ash borer in North America. Divers. Distrib. 20, 847-858. doi: 10.1111/ ddi. 12212

Simberloff, D., and Gibbons, L. (2004). Now you see them, now you don't!population crashes of established introduced species. Biol. Invasions 6, 161-172. doi: 10.1023/B:BINV.0000022133.49752.46
Slippers, B., Hurley, B. P., and Allison, J. (2020). Harnessing the potential of precision pest management in plantation forests. South For. 82, 197-201. doi: 10.2989/20702620.2020.1813651

Smith, C. M., Langor, D. W., Myrholm, C., Weber, J., Gillies, C., and Stuart-Smith, J. (2013). Changes in white pine blister rust infection and mortality in limber pine over time. Can. J. For. Res. 43, 919-928. doi: 10.1139/cjfr-2013-0072

Stadler, B., Müller, T., Orwig, D., and Cobb, R. (2005). Hemlock woolly adelgid in New England forests: canopy impacts transforming ecosystem processes and landscapes. Ecosystems 8, 233-247. doi: 10.1007/s10021-003-0092-5

Sun, B., Bogdanski, B. E., and Van Hezewijk, B. (2019). The Economic Feasibility of the Gypsy Moth Eradication Program in British Columbia. Victoria, Canada: Canadian Forest Service, Natural Resources Canada.

Trotter, R. T., Pepper, E., Davis, K., and Vasquez, R. (2019). Anisotropic dispersal by the Asian longhorned beetle (Anoplophora glabripennis): quantifying spatial risk and eradication effort with limited biological data. Biol. Invasions. 21, 1179-1195. doi: 10.1007/s10530-018-1894-x

Turgeon, J., Orr, M., Grant, C., Wu, Y., and Gasman, B. (2015). Decade-old satellite infestation of Anoplophora glabripennis motschulsky (Coleopterai cerambycidae) found in Ontario, Canada outside regulated area of founder Ppopulation. Coleopt. Bull. 69, 674-678.

Villari, C., Herms, D. A., Whitehill, J. G. A., Cipollini, D., and Bonello, P. (2016). Progress and gaps in understanding mechanisms of ash tree resistance to emerald ash borer, a model for woodboring insects that kill angiosperms. New Phytol. 209, 63-79. doi: 10.1111/nph.13604

Webber, J. F. (2000). "Insect vector behaviour and the evolution of Dutch elm disease," in The Elms. Breeding, Conservation and Disease Management, ed. C. P. Dunn (Boston: Kluwer Academic Publishers), 47-60.

Yelenik, S. G., and D'Antonio, C. M. (2013). Self-reinforcing impacts of plant invasions change over time. Nature 503, 517-520.

Zilahi-Balogh, G., Humble, L. M., Foottit, R., Burleigh, J., and Stock, A. (2017). History of the balsam woolly adelgid, Adelges piceae (Ratzeburg), in British Columbia with notes on a recent range expansion. J. Entomol. Soc. Br. Columbia $113,21-38$.

Conflict of Interest: The authors declare that the research was conducted in the absence of any commercial or financial relationships that could be construed as a potential conflict of interest.

Copyright (c) 2021 Allison, Marcotte, Noseworthy and Ramsfield. This is an openaccess article distributed under the terms of the Creative Commons Attribution License (CC BY). The use, distribution or reproduction in other forums is permitted, provided the original author(s) and the copyright owner(s) are credited and that the original publication in this journal is cited, in accordance with accepted academic practice. No use, distribution or reproduction is permitted which does not comply with these terms. 